\title{
Improving an organization functioning in risk conditions in accordance with ISO 9001: 2015
}

\author{
Hanna Gołaś ${ }^{1,}{ }^{*}$, Anna Mazur ${ }^{1}$ and Józef Gruszka ${ }^{1}$ \\ ${ }^{1}$ Poznan University of Technology, Faculty Engineering Management, Strzelecka 11, \\ 60-965 Poznan, Poland \\ *hanna.golas@put.poznan.pl
}

\begin{abstract}
ISO 9001 quality management systems are very popular in Poland. The changes in the standard introduced in 2015 related to, among other things, the treatment of risk management as a vital part of corporate governance, will make companies improve the management of their systems in this respect.

The aim of the article is to present a model of organization improvement which takes into account the requirements associated with risk included in the standard ISO 9001: 2015, supported by the guidelines for risk management in accordance with ISO 31000: 2012. The model is the result of compilation work based on the cooperation of the authors of the article with more than 20 industrial enterprises over the past three years.
\end{abstract}

Keywords: ISO 9001: 2015, ISO 31000: 2012, risk, risk management, improvement of the organization

\section{Introduction}

Enterprises operating in turbulent environments are interested in exploring the factors that shape their future and in analysing scenarios of what their future may bring. Company managers analyse the potential of achieving their goals and projects, but also analyse the situations that can end up in failure. Company managers aiming at achieving long-term success in the form of tangible economic benefits attach great importance to the system approach to management [1,2], which is why skilful risk management has become so important for them. The term risk management should be understood as coordinated action concerning the management and supervision of the organization with regard to risk [3]. In every action of the organization there are elements of risk that require diagnosis, planning, monitoring and improvement. Risk management helps to support the decision-making process, taking into account volatility, as well as those events and circumstances which affect achievement of goals or its lack. The risk management process involves the use of logical and systematic methods throughout the management process, including identification, analysis and assessment of risks, as well as an active response to the already observed risk. In addition, risk management is the basis for control and inspection of risks, as well as for the communication within groups of employees both inside and outside the company. That is why the 2015 upgrade of ISO 9001:2015 was particularly focused on the issues of risk, which became more pronounced and is built into the entire enterprise management system [4]. Quality management systems enjoy great popularity in Poland. In 2014, 9608 Polish enterprises had valid ISO 9001: 2008 certificates [5]. Even today, although the Polish Committee for Standardization has not yet issued a Polish version of ISO 9001: 2015, many companies are interested in adapting their systems to the current standard. The aim of the 
article is to present a model for the improvement of organizations in terms of risk management. The proposed solution is the result of compilation work, which comprises the experience of the authors in improving quality management systems in manufacturing companies by taking into account the implementation of risk management processes in those organizations.

The research methods applied in the work were mainly interviews with senior management and inspection of the functioning of the quality management systems as well as source documentation analysis.

\section{Risk in quality management systems according to ISO 9001: 2015}

The 2015 upgrade of ISO 9001 makes the concept of risk more pronounced and builds it into the whole management system. Therefore a key change in the updated ISO 9001: 2015 is a systemic approach to risk, not treating it as an individual element of the Quality Management System. Risk based thinking in the previous editions of the standards was hidden under the concept of preventive action [6,7,8]. The upgrade calls attention to carrying out preventive measures to eliminate potential non-conformities, by analysing any non-conformities that happen, and then taking action to prevent their relapse [4]. The standard makes many references to the issue of risk management. Table 1 shows in which areas of the quality management system it will be necessary to implement the assumptions of the concept of risk management.

Table 1. References to risk in ISO 9001: 2015 (authors' own compilation based on $[4,9,10,11,12,13]$ )

\begin{tabular}{|c|c|}
\hline ISO 9001:2015 & Reference to risk \\
\hline $\begin{array}{l}\text { 4.1 Understanding } \\
\text { of organisation } \\
\text { and its context }\end{array}$ & $\begin{array}{l}\text { The organization should define the external and internal risk factors that are relevant to the } \\
\text { purpose of its activities but also those that significantly affect its ability to achieve the intended } \\
\text { results. The organization should regularly monitor and review the information on these factors. }\end{array}$ \\
\hline $\begin{array}{l}4.2 \text { Understanding } \\
\text { of needs and } \\
\text { expectations of } \\
\text { stakeholders }\end{array}$ & $\begin{array}{l}\text { Taking into account the impact (actual or potential) on the organization's ability to deliver } \\
\text { products and services that meet the specified requirements, the organization should define the } \\
\text { stakeholders important for its QMS and the risks and opportunities related to them, as well as } \\
\text { the requirements of the stakeholders relevant to the QMS in order to identify risks and } \\
\text { opportunities. } \\
\text { The organization should monitor and review the information on its stakeholders and their } \\
\text { requirements. }\end{array}$ \\
\hline $\begin{array}{l}\text { 4.4 Quality } \\
\text { management } \\
\text { system and its } \\
\text { processes }\end{array}$ & $\begin{array}{l}\text { The organization shall determine the processes needed for its quality management system, it } \\
\text { should also refer to the risks and opportunities in these processes in accordance with the } \\
\text { methods accepted for the risks and opportunities related activities. These activities may include } \\
\text { risk avoidance, risk-taking in order to take advantage of an opportunity, elimination of sources } \\
\text { of risk, change of the probability or consequences of risk, risk sharing or its informed } \\
\text { acceptance. Opportunities may lead to adopting new practices, introduction of new products, } \\
\text { opening new markets, winning new customers, building partnerships, using new technologies } \\
\text { and other desirable and real possibilities to meet the needs of the organization or its customers. }\end{array}$ \\
\hline $\begin{array}{l}\text { 5.1.1 General } \\
\text { provisions }\end{array}$ & $\begin{array}{l}\text { Top management should demonstrate leadership and commitment in relation to the QMS by } \\
\text { promoting the process approach and thinking in terms of risk. }\end{array}$ \\
\hline $\begin{array}{l}\text { 5.1.2 Customer } \\
\text { orientation }\end{array}$ & $\begin{array}{l}\text { Top management should demonstrate leadership and commitment with regard to customer } \\
\text { orientation ensuring that the risks and opportunities that may affect the conformity of products } \\
\text { and services and the ability to improve customer satisfaction have been identified and are } \\
\text { undertaken. }\end{array}$ \\
\hline 6.1 Risk and & When planning a QMS the organization should consider the issues related to the context of the \\
\hline
\end{tabular}




\begin{tabular}{|l|l|}
\hline $\begin{array}{l}\text { opportunities } \\
\text { related action }\end{array}$ & $\begin{array}{l}\text { organization and the needs and expectations of its stakeholders, as well as to identify risks and } \\
\text { opportunities to which reference should be made to ensure that the QMS can achieve the desired } \\
\text { result. These results can be improved, among other things, by preventing the occurrence of } \\
\text { undesirable effects or by reducing them in order to achieve continuous improvement. The } \\
\text { organization should plan its activities relating to risks and opportunities in order to integrate and } \\
\text { implement activities in the QMS processes and to evaluate the effectiveness of these measures. } \\
\text { Actions taken in relation to risks and opportunities should be proportionate to the potential } \\
\text { impact on the conformity of products and services. }\end{array}$ \\
\hline $\begin{array}{l}\text { 8.1 Planning and } \\
\text { supervision of } \\
\text { operational } \\
\text { activities }\end{array}$ & $\begin{array}{l}\text { The organization should plan, implement, maintain and supervise the processes needed to meet } \\
\text { the requirements of the supplied products and services and to implement activities relating to the } \\
\text { risks and opportunities. }\end{array}$ \\
\hline $\begin{array}{l}\text { 9.1.3 Analysis and } \\
\text { evaluation }\end{array}$ & $\begin{array}{l}\text { The organization should analyse and evaluate the relevant monitoring and measurement data } \\
\text { and information. The results of the analysis should be used to evaluate the effectiveness of } \\
\text { actions related to risks and opportunities. }\end{array}$ \\
\hline $\begin{array}{l}\text { 10.2 10.2 Non- } \\
\text { conformity } \\
\text { and corrective } \\
\text { action }\end{array}$ & $\begin{array}{l}\text { In a situation where there is non-conformity, e.g. arising from a claim, the organization should } \\
\text { update the risks and opportunities identified during the planning stage if necessary. }\end{array}$ \\
\hline
\end{tabular}

The previous ISO 9001: 2008 standard did not emphasize the significance of risks and opportunities, however knowledgeable managers were interested in enhancing their management systems by the analysis of the threats that may arise in projects, processes or tasks [14]. The current ISO 9001: 2015 standard does not suggest which methods and tools should be used in risk management. In each of the areas identified in Table 1, organizations should develop their own methods of dealing with risks and opportunities.

\section{A model for improvement of an organization functioning under risk}

An analysis of the information collected in the investigated companies, the structure of which is shown in Table 2, lead to the following conclusions with regard to the approach to risk as part of the quality management system:

1. Every decision in a company has a financial impact.

2. Top management is responsible for the level of risk in a company.

3. For effective risk management it is necessary to determine the boundary conditions - to determine the context of the organization.

4. Risk management provides awareness of all the risks faced by an organization, their consequences and possible scenarios leading to their materialization, which allows for the preparation of preventive measures.

5. Risk management provides consistency for managing an organization with a vision, mission and strategy.

6. Results of risk analysis and assessment provide top management with comprehensive risk information.

7. A risk strategy is reflected in the duties, authority and responsibilities of process owners.

8. Risk management helps managers and process owners to monitor the activities of a company and to manage and supervise the key risks of the organization.

9. Identification and recognition of hazards and their assessment allow lower level management to take risks in a controlled manner and in accordance with the objectives of the company.

10. Risk management provides the organization with common, transparent criteria for evaluation, comparison, and procedures when dealing with risks in completely different 
areas of organization activity (e.g. the risk of losing a customer, the risk of an IT systems failure).

11. The organization is prepared for the materialization of risks, thus its efficiency of operations is increased.

Table 2. The structure of the surveyed companies

\begin{tabular}{|c|l|c|}
\hline Item & Characteristic & Description \\
\hline 1 & Number of surveyed companies & 23 \\
\hline 2 & Number of manufacturing companies & 19 \\
\hline 3 & Average annual employment in the surveyed enterprises & 86 \\
\hline 4 & Possession of ISO 9001: 2008 & 23 \\
\hline 5 & Top management trained in risk management according to ISO 31000: 2012 & 19 \\
\hline
\end{tabular}

Figure 1 shows a model of organization improvement which takes into account the risk management process.

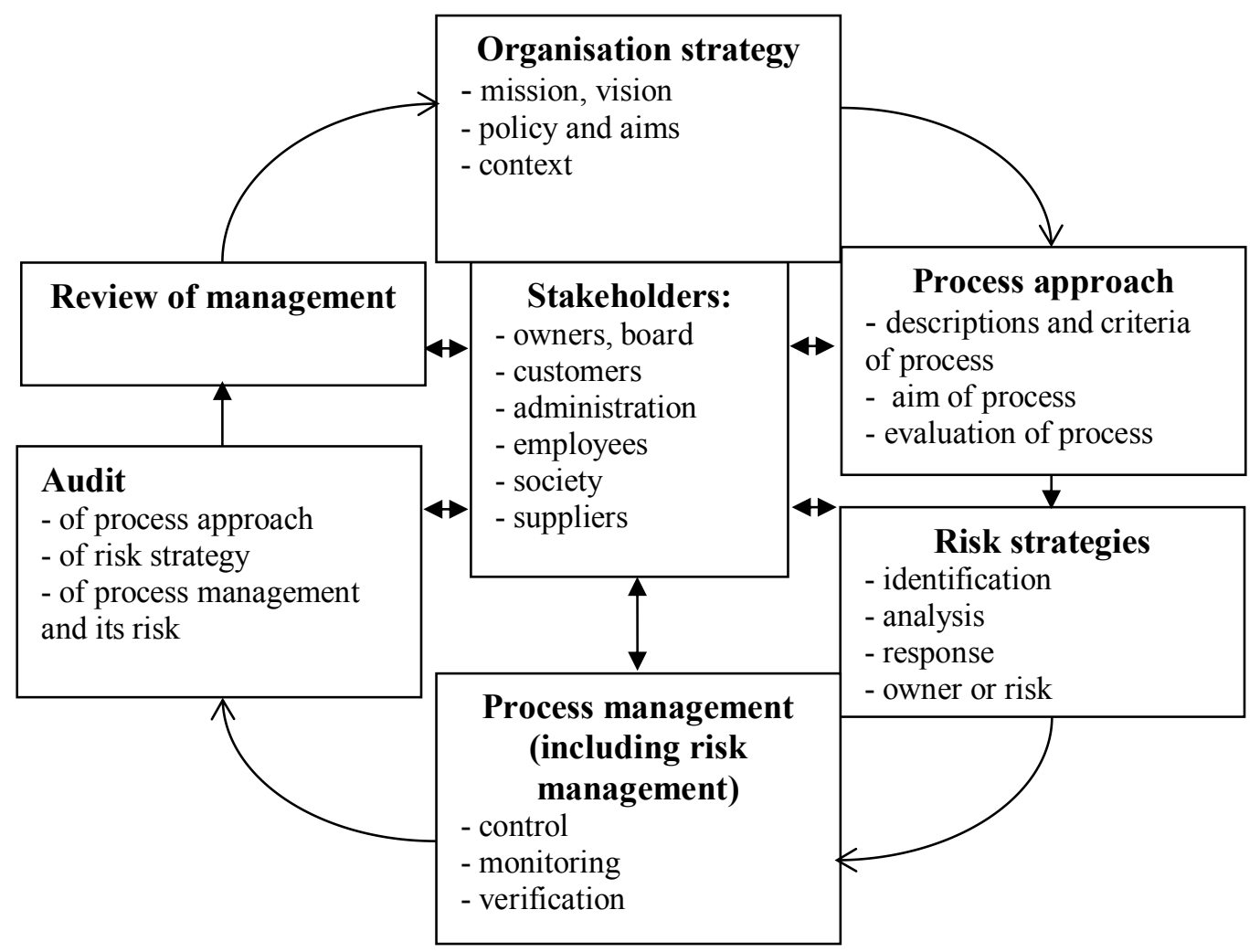

Figure 1. A model of organization improvement with regard to risk [authors' own elaboration]

The model takes into account improvement of the process approach in an organization, recommended by ISO 9001, and the risk management process woven into the organization's management system. The model has the PDCA cycle at its basis, where the areas of organizational strategy, stakeholders, the process approach and risk strategies are part of Plan, Do is process management, Check is audit, while Act is a review of the management system.

\section{Conclusions}

The key change in the updated ISO 9001: 2015 standard is a systemic approach to risk, rather than treating it as a single element of a Quality Management System. The approach based on risk assessment activates the part of strategic planning whose aim is to ensure trust in the 
organization by consistently providing customers with appropriate goods and services, and thereby increasing customer satisfaction. Inclusion of the risk management process in the process approach and its continuation during audits and management reviews provides a comprehensive approach to risk at every stage of the management and organisation improvement process.

\section{References}

[1] Mazur A., Stachowiak A., The Framework of methodology for identification of organizational maturity with assessment of excellence level of logistics systems, Management between Profit and Social Responsibility (2014) p. 415-422.

[2] Wyrwicka M.K., Technological Culture and Its Interpretation: Research Results in Poland, Human Factors and Ergonomics in Manufacturing \& Service Industries Vol. 21 Iss. 2 (2011) p. 178-187.

[3] ISO Guide 73:2009, Risk management. Vocabulary, International Organization for Standardization, Brussels.

[4] ISO 9001:2015, Quality management systems. Requirements, International Organization for Standardization, Brussels.

[5] World distribution of ISO 9001 certificates in 2014, http://www.iso.org (from 13.06.2016).

[6] Scierski J.M., Risk management in normalized quality systems, Aktualne problemy podnikovej sfery 2012, ed. Majtan S. (2012), p. 454-462.

[7] Gołaś H., Mazur A., Mrugalska B., Application of risk analysis and quality control methods for improvement of lead molding process, Metalurgija Vol. 55 Iss. 4 p. 811-814.

[8] Misztal A., Bachorz S., Quality planning of parts machine production based on housing of cylinder head milling machines, Applied Mechanics and Materials, Vol. 657 (2014) p. 986-990.

[9] Ragin-Skorecka K., Agile Enterprise: A Human Factors Perspective, Human Factors and Ergonomics in Manufacturing \& Service Industries, Vol. 26 Iss. 1 (2016) p. 5-15.

[10] Liu WH, Wang YJ, Quality control game model in logistics service supply chain based on different combinations of risk attitude, International Journal of Production Economics, Vol. 161 (2015), p. 181-191.

[11] Zhou ZZ, Johnson ME, Quality Risk Ratings in Global Supply Chains, Production and Operations Management, Vol. 23, Iss. 12 (2014), p. 2152-2162.

[12] Aven T., On the meaning of the special-cause variation concept used in the quality discourse And its link to unforeseen and surprising events in risk management, Reliability Engineering \& System Safety, Vol. 126 (2014), p. 81-86.

[13] Jasiulewicz-Kaczmarek M., Saniuk A., 2015, Human factor in Sustainable Manufacturing, Editors: M. Antona, C. Stephanidis, Universal Access in Human-Computer Interaction. Access to the Human Environment and Culture, LNCS Vol. 9178, pp.444 - 455.

[14] Lenhardt U., Beck D., Prevalence and quality of workplace risk assessments - Findings from a representative company survey in Germany, Safety Science, Vol. 86 (2016), p. 48-56.

[15] Gonzalez M.R., Torres F., Yoldi V., Arcega F., Plaza I., Model for Integrated Management of Quality, Labor Risks Prevention, Environment and Ethical Aspects, Applied to R\&D\&D\&I and Production Processes in an Organization, 4th Manufacturing Engineering Society International Conference (MESIC 2011), AIP Conference Proceedings, Vol. 1431 (2012) p. 912-919. 